University for Business and Technology in Kosovo

UBT Knowledge Center

Oct 28th, 9:00 AM - 10:30 AM

\title{
Residential building stock transformation in years and strategies for the future - Albanian case
}

\author{
Jujian Veleshnja \\ Polytechnic University of Tirana \\ Miranda Rashani \\ University of Pristina
}

Follow this and additional works at: https://knowledgecenter.ubt-uni.net/conference

Part of the Architecture Commons

\section{Recommended Citation}

Veleshnja, Jujian and Rashani, Miranda, "Residential building stock transformation in years and strategies for the future - Albanian case" (2017). UBT International Conference. 16.

https://knowledgecenter.ubt-uni.net/conference/2017/all-events/16

This Event is brought to you for free and open access by the Publication and Journals at UBT Knowledge Center. It has been accepted for inclusion in UBT International Conference by an authorized administrator of UBT Knowledge Center. For more information, please contact knowledge.center@ubt-uni.net. 


\title{
Residential Building Stock Transformation in Years and Strategies for the Future - Albanian Case
}

\author{
Juljan Veleshnja ${ }^{1}$, Miranda Rashani² \\ ${ }^{1}$ Department of Urbanism, Faculty of Architecture and Urbanism FAU, \\ Polytechnic University of Tirana, \\ ${ }^{2}$ Department of Architecture, Faculty of Civil Engineering and Architecture, \\ University of Pristina, \\ juljan.veleshnja@gmail.com¹ ${ }^{1}$ miranda.rashani@uni-pr.edu ${ }^{2}$
}

\begin{abstract}
The paper focuses on the residential building blocks of the communism period, explaining their transformation. Firstly in the paper is explained why this building category needs to be taken in exam, and the existence of EU legislation which address the necessary intervention. In the following is described a wide panorama of how the residential blocks took birth, how the communism period influenced it, and the transformation during years. The paper finalizes underlying the importance of a deep analysis of the residential block in order to proceed with the intervention actions of possible deep renovation.
\end{abstract}

Keywords: Residential Blocks, Building Stock, Energy Efficiency, Deep Renovation

\section{Introduction}

Problem statement. The awareness about the climate change brings the attention of the society toward the sustainable development. The development of our society bases on the energy consumption, which is in strong relation with the depletion of fossil fuels and climate change. The European Council aiming the reduction of the $\mathrm{CO}_{2}$ emission has made a long term commitment with the target of an 88 to $91 \%$ cuts in emissions by 2050 [1] to EU and other industrialized countries. There are adopted different polices by the European Commission regarding the energy consumption.

Energy is one of the key issues to ensure sustainable development, in this frame the building sector, comprising of the household and service sector, is responsible of about $40 \%$ of the energy consumed in EU, it is the biggest energy user, bigger than industry and road transport ${ }^{34}$. Residential and services buildings, responsible for this big amount of energy use, are the target of many polices evidencing the considerable potential for energy conservation. The residential building has a larger energy saving potential and benefit than other sectors. The European Directive, on the Energy Performance of Buildings (EPBD), was designed in 2002 due to the great role that the building sector has in the energy consumption. According to this Directive, each building should provide an energy performance certificate. The main objective of the EPBD is to 'promote the improvement of the energy performance of buildings within the community taking into account outdoor climatic and local conditions, as well as indoor climate requirements and cost-effectiveness'.

\footnotetext{
${ }^{34}$ Referring to Final energy consumption, EU-28, 2014 (percentage of total, based on tons of oil equivalent - Source: Eurostat).
} 
Considering the idea of improving the comforts, and the reduction of the energy consumption in the existing residential building blocks, first is crucial to classify and recognize the reason why we need to do retrofitting interventions, which are the buildings to take in examination to go through this process.

It is very important for a construction that is going through a deep renovation process, to understand the typologies of structures, regarding the interested period in which they have been built. Only this way it is possible to propose effective solutions and to fulfil the retrofitting needs [2]. The aim is not to analyse the overall story of these buildings from the time when they were built, but to collect data and evidences regarding its original building projects and construction, the present situation of these residential buildings and the future scenarios of their possible use [3].

Time is an important element; it affects the materials used, necessities, procedures, constructions methods used in that time. From the other hand the market, as a key factor that regulates the expenses and the return from the investment.

Objectives and Utility. The development of good analyses and survey of the residential buildings will help on creating a clear picture of their characteristics, which will serve as a starting point for building up the strategies for the deep renovation interventions.

The tools used for a deep research in the survey of the residential building stock will be different and combined between them: empirical and observational, based on data that need to be gathered and desk research, where historical documents are needed to describe the residential building context. Bringing the intention the existing building stock, with the aim to build a clear picture of the actual situation, and all the steps of transformation, in order to create technical information sheets of different typologies of the residential blocks, based on with do base the future strategies of deep renovation.

\section{Evolution of the Residential Building Block}

The residential building blocks, mainly during the communism period, were designed by type and built several times, spread all over the country, with small changes depending on the budget in disposition for each construction company. The National Building Institute did the design of each typology with architects and experts on the construction field; the design process was centralized in this Institute. For each of these typologies in some cases were done changes and adaptation depending on the site conditions and other constrains, like budget, expertise etc.

The projects done by typologies belong to the period 1952 - 1988, the period under the communist regime. The main aspect that drive the design of various types was the constructive solution of the building [4]. The evolution of the typologies brought changes on the distribution of the functional areas in the interior, to the surface and spatial extension of each apartment and the improvement of the material used. The main types of the residential building blocks, based on the construction solution, are the ones with reinforced ceramic slab; pre-stressed concrete slab; reinforced concrete frame, prefabricated concrete panels; multi-unit block.

The evolution of different types was influenced by the same typologies of other architects or countries but, for ideological reasons, this aspect is visible up to 1970, until when Albania had some political relation and industrial and technological exchange with other communist countries like Russia, Yugoslavia or China.

The typologies can be described in different way as: the distribution in plant of each residential unit, the evolution of construction solution, economical budget and the material used. 


\section{Housing Policies in Communism Period}

In the communist period, the state has a social obligation towards the worker to provide him a house. The accelerated urbanization process during the first years of communist period was caused also by the quick industrialization of the country and the need to provide accommodations to the working force close to their working places. On the other hand, housing needs was increased due to very low renting costs. A major reason in that big demand for housing was also the lifestyle and the mentality of those years. The number of families increased very quickly, during $1969-1979$ the growth was $35 \%$ as compared to the population growth, which was $25 \%$.

Table 2. Buildings in construction period [5].

\begin{tabular}{|c|c|c|c|c|c|c|}
\hline & \multicolumn{3}{|c|}{ Numbers } & \multicolumn{3}{c|}{$\%$} \\
\hline Periods & Total & Urban & Rural & Total & Urban & Rural \\
\hline Total & 507180 & 140493 & 366687 & 100 & 100 & 100 \\
\hline-1945 & 40438 & 17042 & 23396 & 8 & 12,1 & 6,4 \\
\hline $1945-1960$ & 68468 & 16510 & 51958 & 13,5 & 11,7 & 14,2 \\
\hline $1961-1980$ & 154701 & 29932 & 124769 & 30,5 & 21,4 & 34,1 \\
\hline $1981-1990$ & 115727 & 22074 & 93653 & 22,8 & 15,7 & 25,5 \\
\hline $1991-1995$ & 52880 & 23261 & 29619 & 10,4 & 16,6 & 8 \\
\hline $1996+$ & 74966 & 31674 & 43292 & 14,8 & 22,5 & 11,8 \\
\hline
\end{tabular}

Providing houses for the working force was not only a social responsibility but also together with building materials industry were an important source of employment. The building blocks construction reached its peak during the period 1960-1988, throughout which $75 \%$ of the total housing construction during the communist period took place.

In the late ' 80 s almost $80 \%$ of the Tirana's population lived in apartments. A significant factor which helped in the fast fulfil of the housing need was voluntary work in construction industry. Even though the voluntary work contribution, still the housing need was not completely fulfilled.

\section{Residential Building Tenancy Form and Physical Conditions}

During this period, there were two typologies of building blocks: state sector of rental housing and the private endowment of housing, 202,000 dwelling units, more or less $70 \%$ of the housing were public rental houses managed by the state. Due to these reason the design standards of the communist residential building blocks were relatively low, according to the norms of projection of that period of 4-6 m²/person of bedroom surface or $46.7 \mathrm{~m}^{2} ; 61.7 \mathrm{~m}^{2} ; 71.7 \mathrm{~m}^{2}$ for usable floor area corresponding to apartment structures of one-bedroom; two-bedroom and three-bedroom apartments [6]. Referring to this information the average area per person is around $11.6 \mathrm{~m}^{2}$ for a normal family with four people, which is less than the average of other Eastern - European countries of $17.5 \mathrm{~m}^{2}$. 

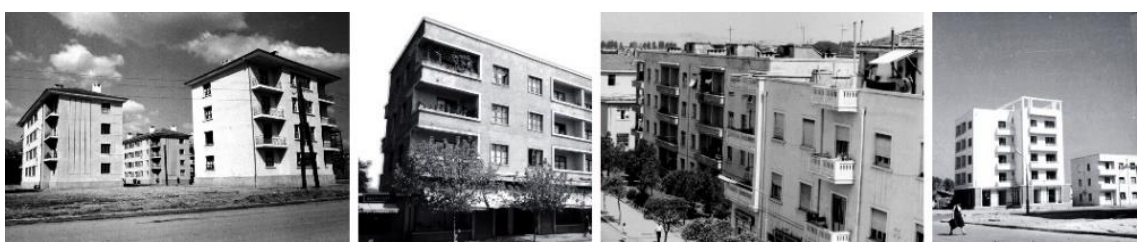

Fig. 9. Tirana city during communism period, 'new' residential blocks, source: Central Technical Archive of Construction

Some factors that caused the disparaging housing situations were as problems in procedures which has to do with the size of household and the size of apartment; the fluctuations of household size and continuous transfer through internal circulation; partial variation of the size and type of apartments in compliance with high rates of birth. The communist residential building blocks were 4-6 floor apartment buildings, constructed with reinforced concrete and bricks, or prefabricated components. Due to the urgent need for housing, the state took in consideration only the quantitative part of the construction. Referring to this the physical conditions of the building was very poor and the housing quality runs down gradually [7].

\section{Spontaneous Transformation of the Residential Block in Tirana}

There are many factors contributing in the way in which the communist residential building blocks were transformed, most of them in an informal way.

According to the annotations done on the frame, the informal interventions can be classified referring to their physical internal and external features, like follows: Horizontal transformations, Vertical transformations and Infill transformations.

Internal transformations have to do mostly with modifications in function of the apartment, usually from residential apartment to a commercial one, positioned in the ground and first floors. In some cases, the internal transformation is done in parallel with horizontal extensions of the apartment, to provide accommodations for residential usages too. This is the typical case of private usage of the private property.

External vertical transformations were realized in the form of: a continuous multi-storey extension lengthways the complete height of the construction, random extensions in the upperfloors and terrace additions.

Infill transformations are construction interventions in the public land inside the communist residential building block. Infill transformations typically are positioned in-between the communist flats as individual single or multi-story constructions. Even though they are not interventions done to the existing building they are a morphological element, establishing the urban fabric created due to these housing typology, instead of the block as a construction element. These interventions were done in the communist residential building blocks in two ways: in a formal way - typically they have been the outcome of the implementation of the law on restitution and compensation of property, when property possessors were compensated with for their original property with public land. The possessor later on developed this land.

In an informal way - public land has been engaged by the construction of mostly one to two story commercial units. This land has been turned into private property most of the times through legalization practices However, transformations of the communist-era housing block, besides being multi-dimensional in terms of property relations which cause them and which derive from them, they are challenging also in quantitative terms. 


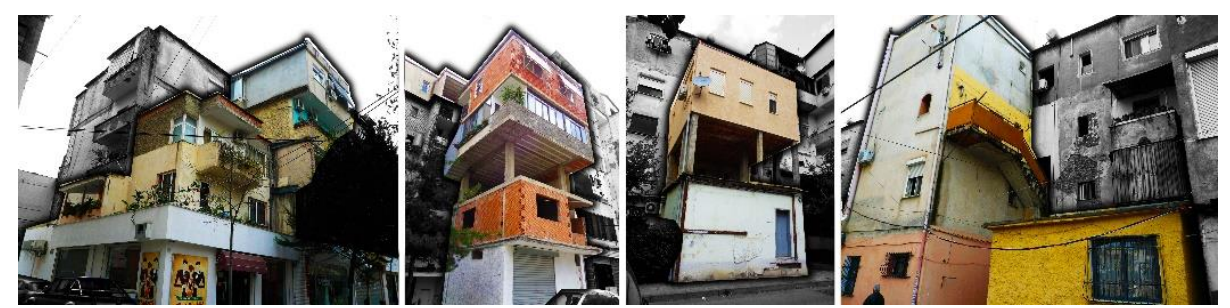

Fig. 2. Residential building, individual transformation, Tirana, 2016, source Author (J.V.)

During the years 1995-1996, when people moved massively from rural areas to Tirana, the occurrence of informal transformations of the communist residential building blocks became apparent. Many of the migrating population from rural areas were placed informally in single houses in the outsides of Tirana. The state authority was weak during those years, for this issue, so people profited from their weakness to proceed with informal interventions.

\section{Technical Information Sheets for the Typologies of the Residential Blocks}

In order to investigate and better understand the typological, constructive and technological characteristics of the residential building block during the communism period 1945-1990, the most significant typologies has to be examined. As explained previously, the construction residential sector was operating with types and any of them, with small changes, was "distributed" and built around all the Albanian territory, with a high concentration in the urban areas (cities). There are roughly 15 significant typologies, based on an empirical and observational research on the territory, but although on the descriptive research done by The Central Technical Archive of Construction in Tirana [8], that has evidenced the most used typologies, which means the most spread in the territory.

The samples selection should be deliberately heterogeneous, because the intention is to offer a panorama as representative as possible of this period of the residential construction sector. One of the main criteria for the choice of the samples taken in study is the chronological order, because it better shows the evolution in this sector. Other important characteristics of the building that helps to have a complete panorama of the residential building stock are as follows: the year of construction, location in the city, type of costumer, designer, layout of the building, types of apartments, layout of the apartments, technological solution.

\section{CONCLUSIONS}

This paper tried to bring the focus to the importance that the residential building stock has not only for the aspect of energy consumption. The legislative obligations dictate that each building should provide an energy performance certificate, and if necessary also deep renovation intervention. Before taking any action, it is important to make e deep analyses of the residential existing stock.

This paper tried to build an exhaustive general overview of the residential building blocks during years, focusing mainly to the constructions during the communist period. What comes out is the importance of building up technical information sheets for different typologies of the residential blocks. All the experts that has to go through the process of: preparation of the energy 
performance certificate or the deep intervention project of the residential building blocks during 1960-90, can use the technical sheets.

\section{References}

1. European Commission. (2011). Progress Report on the Europe 2020 Strategy. Brussels: European Commission.

2. Giebeler, G., Krause, H., Fisch, R., Musso, F., Lenz, B., \& Rudolphi, A. (2009). Refurbishment manual: maintenance, conversions, extensions. Basel: Birkhäuser Vertag AG

3. Zijlstra, H. (2009). Analysing Buildings from Context to Detail in Time. ABCD Research Method. Amsterdam: IOS Press.

4. Aliaj, B. (1999). Housing Models in Albania between 1945-1999. Tirana: Co/PLAN.

5. Bërxholi, A. (2000). Regjistrimet e përgjithshme të popullsisë në Shqipëri. Tirana: Akademia e Shkencave.

6. Andoni, D. (2000). The Impact of Housing Policy on the Poor in Albania - Dissertation. Rotterdam: University of Lund and Institute for Housing and Urban Development Studies.

7. Misja, V., \& Misja, A. (2004). Vështrim mbi situatën e banesave në Shqipëri. Tirana: Akademia e shkencave.

8. Lulo, K. (1999). Buletin Informativ. Tirana: The Central Technical Archive of Construction. 